\title{
Effect of GnRH conjugated to pokeweed antiviral protein on reproductive function in adult male dogs
}

\author{
K. Sabeur ${ }^{1}$, B. A. Ball ${ }^{1 *}$, T. M. Nett ${ }^{2}$, H. H. Ball ${ }^{1}$ and I. K. M. Liu ${ }^{1}$ \\ ${ }^{1}$ Department of Population Health and Reproduction, University of California, Davis, CA 95616, USA; \\ and ${ }^{2}$ Department of Biomedical Sciences, Colorado State University, Fort Collins, CO 80523, USA
}

This study evaluated the effect of a GnRH analogue conjugated to the cytotoxin, pokeweed antiviral protein (PAP), on reproductive function in adult, male dogs. Four dogs received $0.0042 \mathrm{mg} \mathrm{GnRH-PAP} \mathrm{g}^{-1}$ hourly for $36 \mathrm{~h}$, and four other dogs received $0.1 \mathrm{mg} \mathrm{GnRH}-\mathrm{PAP}$ $\mathrm{kg}^{-1}$ as one bolus injection daily for three consecutive days. One dog received a single bolus $\left(0.1 \mathrm{mg} \mathrm{kg}^{-1}\right)$. Three adult male dogs received GnRH without the PAP conjugate, as controls. Twenty-five weeks after the initial treatment, all treated dogs received $0.1 \mathrm{mg}$ GnRH-PAP $\mathrm{kg}^{-1}$ as a single administration, whereas dogs in the control group received $0.0045 \mathrm{mg} \mathrm{kg}^{-1}$ of the GnRH analogue. Serum concentrations of testosterone and LH were determined by radioimmunoassay, and testis size was measured for 9 months after treatment. Stimulation tests $\left(5 \mu \mathrm{g} \mathrm{GnRH} \mathrm{kg}{ }^{-1}\right)$ were used to evaluate LH release $(-15,0,30,60,90,120 \mathrm{~min})$, which was assessed by measuring area under the curve. Serum testosterone concentrations were significantly lower $(P<0.05)$ after treatment in the bolus and hourly groups than in the control group. Testosterone concentrations fell to less than $50 \mathrm{pg}$ $\mathrm{ml}^{-1}$ in three of four dogs in the bolus group and one of four dogs in the hourly group by week 8-9 after treatment. Basal LH was lower $(P<0.05)$ in the bolus and hourly groups than in the control group between weeks 0 and 33 after treatment. Treatment with $\mathrm{GnRH}-\mathrm{PAP}$ reduced $(P<0.05)$ LH release after $\mathrm{GnRH}$ stimulation in the bolus and hourly groups compared with the control group. Testis volume was lower $(P<0.05)$ in all treated versus control dogs. In conclusion, administration of the conjugate GnRHPAP at a 25 week interval resulted in a major disruption of reproductive parameters in male dogs; this effect was maintained for 11-12 weeks after a second injection of GnRH-PAP.

\section{Introduction}

Reproductive function in mammalian species is regulated by the hypothalamic-pituitary-gonadal axis. Although there are considerable differences among species in the underlying mechanisms that regulate reproductive function, certain aspects of neuroendocrine regulation of reproduction are very highly conserved in mammals. Specifically, the pituitary production of two hormones, FSH and LH, plays a critical role in the development and regulation of gonadal functions, including the production of gametes and sex steroid hormones. Pituitary secretion of $\mathrm{FSH}$ and $\mathrm{LH}$ is in turn controlled by $\mathrm{GnRH}$, which acts as the 'master' hormone regulating reproductive function. $\mathrm{GnRH}$ is a decapeptide synthesized in neuronal cell bodies distributed diffusely across the basal forebrain and is secreted from neuronal terminals in the median eminence. Once secreted, GnRH enters the portal vessels and is then transported to the anterior pituitary via the hypothalamic-pituitary portal system. $\mathrm{GnRH}$ has

*Correspondence

Email: baball@ucdavis.edu been a useful tool for studying basic aspects of the hypothalamo-pituitary-gonadal axis as well as a target for the regulation of reproduction.

It has been recognized for many years that $\mathrm{GnRH}$ is a very desirable target for contraception or sterilization in humans and in animals (Ladd, 1993). Because GnRH acts through specific, high-affinity receptors on gonadotrophs, the specificity of the interaction of $\mathrm{GnRH}$ with its receptors on these cells has been used to target a variety of cytotoxic agents to disrupt pituitary gonadotrophs. The approach of coupling cytotoxic agents to $\mathrm{GnRH}$ has been used in the therapy of a number of tumours that possess $\mathrm{GnRH}$ receptors and thereby provide a specific targeting mechanism for the cytotoxic agent (Nagy et al., 1996; Kovacs et al., 1997; Nechushtan et al., 1997; Paalyi et al., 1999). The present study used a novel approach on the basis of GnRH conjugated to a cytotoxic protein, pokeweed antiviral protein (PAP), to directly target $\mathrm{GnRH}$ receptors on gonadotrophs.

The administration of GnRH-PAP offers the potential to target and disrupt the secretion of the reproductive hormones, $\mathrm{LH}$ and $\mathrm{FSH}$, by the pituitary gland without adversely affecting the secretion of other pituitary 
hormones. The potential success of this type of approach has been demonstrated by tests conducted in sheep in which GnRH-PAP reduced the secretion of LH for a period of at least 6 months after administration (Nett et al., 1999). The application of this approach in companion animals provides a unique opportunity to specifically target and eliminate reproductive function by disrupting both behavioural aspects of reproduction as well as gamete production in both males and females. The objective of the study reported herein was to evaluate the feasibility of this approach in adult male dogs by determining the effect of GnRH-PAP on testosterone secretion, LH release and testis size.

\section{Materials and Methods}

Twelve adult male dogs (mixed breed) were provided by Animal Resource Services, University of California, Davis. Animal research was conducted under a protocol approved by the University of California Animal Use and Care Administrative Advisory Committee.

The GnRH-PAP conjugate was prepared as described below. GnRH used in the stimulation test was obtained from Calbiochem (La Jolla, CA); ${ }^{3}[\mathrm{H}]$-testosterone was obtained from New England Nuclear (Boston, MA); and testosterone antibody (S250) was kindly supplied by G. Niswender.

\section{Purification of PAP}

PAP was purified as described by Irvin (1983), with the following minor modifications. Briefly, pokeweed leaves were homogenized with $5 \mathrm{mmol}$ sodium phosphate $\mathrm{I}^{-1}$, $\mathrm{pH}$ 6.5, in a Waring blender. The extract containing PAP was filtered through a strainer and centrifuged at $10000 \mathrm{~g}$ for 30 min. PAP in the supernatant was then purified by ammonium sulphate precipitation (40-100\%), Fractogel EMD-CM (EM Science, Gibbstown, NJ) ion-exchange chromatography and DEAE Sepharose CL-6B (Sigma, St Louis, MO) chromatography. The purified protein was dialysed against water and lyophilized. Purity of PAP was assessed by SDS-PAGE (12\% reducing gel).

\section{Conjugation of $D-L y s^{6}-G n R H$ with PAP}

Thiolation of $D-L y s 6-G n R H$. The D-Lys ${ }^{6}-\mathrm{GnRH}$ analogue $\left(9.3 \mathrm{mmol} \mathrm{I}^{-1}\right)$ was iminothiolated with 2iminothiolane (Pierce, Rockford, IL; $11.3 \mathrm{mmol} \mathrm{I}^{-1}$ ) in the presence of $\mathrm{N}, \mathrm{N}$-diisopropylethylamine to produce $\mathrm{SH}-\mathrm{GnRH}$. The yield of the $\mathrm{SH}-\mathrm{GnRH}$ was $60-70 \%$. The progress of the reaction was monitored by $\mathrm{C} 18$ high performance liquid chromatography. The reaction was performed in methanol for $2 \mathrm{~h}$ at room temperature $\left(25^{\circ} \mathrm{C}\right)$. Methanol was evaporated under nitrogen after the reaction. The final product was analysed by mass spectroscopy.

Introduction of a maleimidodobutyryl group into PAP. PAP $\left(0.6 \mathrm{mmol} \mathrm{I}^{-1}\right)$ was dissolved in deoxygenated
$0.05 \mathrm{~mol}$ sodium phosphate $\mathrm{I}^{-1}, 0.1 \mathrm{~mol} \mathrm{NaCl} \mathrm{I}{ }^{-1}$, 1 mmol EDTA I ${ }^{-1}, \mathrm{pH} 7.4$, and mixed with a crosslinker, $\mathrm{N}$-( $\gamma$-maleimidobutyryloxy)sulphosuccinimide (Pierce; $\left.1.8 \mathrm{mmol} \mathrm{I}^{-1}\right)$. The reaction was allowed to proceed for $60 \mathrm{~min}$ at room temperature. This solution $(8 \mathrm{ml})$ was then mixed with the thiolated D-Lys ${ }^{6}-\mathrm{GnRH}(3.6 \mathrm{mmol}$ $\mathrm{I}^{-1}, 4 \mathrm{ml}$ ) dissolved in the same (deoxygenated) phosphate buffer. The molar PAP:peptide ratio was 1:3. After incubation for $50 \mathrm{~min}$ at room temperature, Cys-SH was added and the reaction mixture was acidified to $\mathrm{pH}$ 4.5-5.0 with glacial acetic acid. Some precipitate was removed by centrifugation and the supernatant was applied to a BioGel P-60 column equilibrated in $0.1 \mathrm{~mol}$ $\mathrm{NaCl} \mathrm{I}^{-1}$. The protein fraction (with a molecular weight in the range 29000-32000) containing GnRH-PAP conjugate was desalted on Sephadex G-25 and lyophilized. SDS-PAGE (12\% reducing gel) analysis and mass spectrometry showed that the final product (as expected) was heterogeneous and contained three major fractions: PAP with one GnRH molecule attached, PAP with two GnRH molecules attached, and unconjugated PAP. Unconjugated PAP in the final product was estimated to be in the range $25-35 \%$.

\section{Experimental design}

Nine adult male dogs were administered GnRH-PAP twice, 25 weeks apart. For the first treatment, dogs were divided into three groups according to the dose and frequency of injection. In the first group, four dogs received $0.0042 \mathrm{mg}$ GnRH-PAP kg ${ }^{-1}$ hourly for $36 \mathrm{~h}$ (equivalent daily dose of $0.1 \mathrm{mg} \mathrm{kg}^{-1}$ ). An i.v. catheter (20 GA, 1.88 in, Becton Dickinson Inc., Sandy, UT) was placed on the foreleg of each dog during this $36 \mathrm{~h}$ study. Heparinized saline was injected regularly to maintain the patency of catheters. Dogs were examined daily for 7 days after treatment to detect any local injection reactions or possible systemic effects associated with the treatment. In the second group, four dogs received $0.1 \mathrm{mg}$ GnRH-PAP $\mathrm{kg}^{-1}$ as one i.v. bolus injection daily for three consecutive days. A single dog received one i.v. bolus injection of GnRH-PAP $\left(0.1 \mathrm{mg} \mathrm{kg}^{-1}\right)$. Three adult male dogs received D-Lys ${ }^{6}-\mathrm{GnRH}$ analogue $(0.0045 \mathrm{mg}$ $\mathrm{kg}^{-1}$ i.v., equivalent amount of $\mathrm{GnRH}$ activity to that in the GnRH-PAP) without the PAP conjugate, as controls. Twenty-five weeks after the initial treatment, all treated dogs received $0.1 \mathrm{mg}$ GnRH-PAP kg ${ }^{-1}$ as a single administration, whereas control dogs received $0.0045 \mathrm{mg}$ $\mathrm{GnRH}$ analogue $\mathrm{kg}^{-1}$.

Dogs were examined daily for 7 days after treatment to detect any local injection reactions or possible systemic effects associated with the treatment. Blood samples were taken before the primary treatment and at weekly intervals. The blood samples were always taken in the morning $(09: 00 \mathrm{~h})$ to minimize variation. Sera were separated and stored at $-20^{\circ} \mathrm{C}$ for determination of serum testosterone, $\mathrm{LH}$, thyroxine and cortisol by immunoassay. 
Testis size and development were measured with a caliper at bi-weekly intervals to determine testis length and width. Concentrations of the circulating gonadotrophin, $\mathrm{LH}$, were determined periodically to evaluate the effect of GnRH-PAP treatment on pituitary function. GnRH stimulation tests $\left(5 \mu \mathrm{g} \mathrm{kg}^{-1}\right)$ were used to evaluate the ability of the pituitary gland to respond to exogenous stimulation with $\mathrm{GnRH}$. Blood samples were taken at $-15,0,30,60,90$ and $120 \mathrm{~min}$ of $\mathrm{GnRH}$ treatment. Blood samples were obtained via indwelling catheters placed in the cephalic vein. LH release was assessed by measuring the area under the curve. Serum testosterone, basal $\mathrm{LH}$ and testis size were assessed for 36 weeks after the first GnRH-PAP treatment.

\section{Endocrine assays}

Sera were separated and stored at $-20^{\circ} \mathrm{C}$ for endocrine assays. Serum LH was measured in a standard doubleantibody radioimmunoassay (Nett et al., 1975). The interassay coefficient of variation (CV) for $\mathrm{LH}$ assays was $12.75 \%$. The intra-assay CV was $3.21 \pm 1.16 \%$. The limit of sensitivity for LH assays was $0.79 \mathrm{ng} \mathrm{m}^{-1}$. Serum testosterone was assessed using a radioimmunoassay described by Shille et al. (1979), with some modification. Briefly, testosterone concentrations were determined in diethyl ether extracts. The samples were evaporated to dryness and re-suspended in $0.1 \%$ gelatinPBS. The tracer solution was added immediately after the antibody and samples were incubated overnight at $4^{\circ} \mathrm{C}$. Separation of the antibody-bound steroids was performed by adding dextran-coated charcoal. The interassay CV for testosterone assays was $6.74 \%$. The intra-assay CV was $10.71 \pm 9.30 \%$. The limit of sensitivity for testosterone assays was $18.9 \mathrm{pg} \mathrm{ml}^{-1}$. Cortisol was assayed using an enzymeimmunoassay (Munro and Stabenfeldt, 1985). Thyroxine assay was performed using a radioimmunoassay kit from Diagnostic Products Corporation (Los Angeles, CA).

\section{Statistical analysis}

Data were analysed by repeated-measures ANOVA (Statview; SAS Institute, Cary, NC). Data for testis volume were normalized to pre-treatment values on the basis of the mean testis volume for four monthly determinations before treatment. Data for $\mathrm{LH}$ release after GnRH stimulation were evaluated as area under the curve and were log-transformed before analysis. Data are expressed as mean \pm SEM.

\section{Results}

\section{$L H$ release}

There were effects of treatment $(P=0.06)$ and time $(P<0.01)$ on basal LH concentrations. Basal LH concentrations were lower $(P<0.05)$ in the bolus and hourly

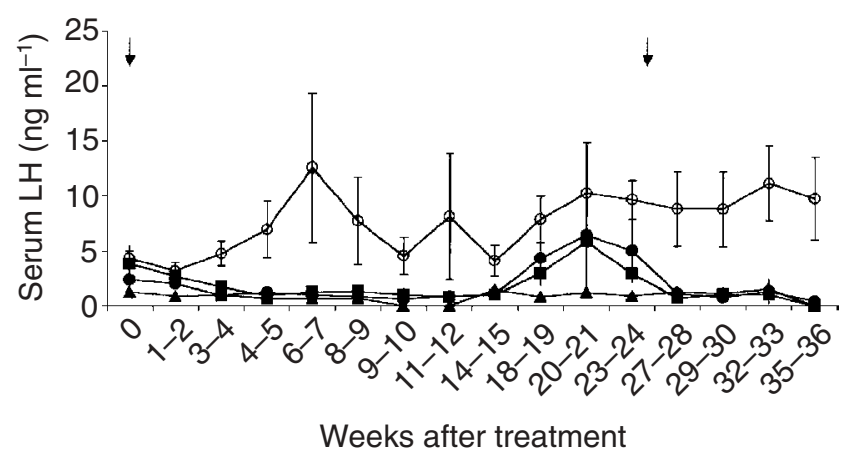

Fig. 1. Basal serum LH concentrations in male dogs treated with $\mathrm{GnRH}-$ pokeweed antiviral protein (GnRH-PAP) or $\mathrm{GnRH}$ alone, from week 0 to weeks 35-36 after treatment. Four dogs received $0.0042 \mathrm{mg} \mathrm{GnRH-PAP} \mathrm{kg}{ }^{-1}$ hourly for $36 \mathrm{~h}(\boldsymbol{\square})$. Four dogs received $0.1 \mathrm{mg} \mathrm{GnRH}-\mathrm{PAP}$ as one bolus injection daily for three consecutive days $(\mathbf{O})$. One dog received a single bolus $(0.1 \mathrm{mg}$ $\left.\mathrm{GnRH}-\mathrm{PAP} \mathrm{kg}{ }^{-1} ; \boldsymbol{\Delta}\right)$. Three dogs received GnRH without the PAP conjugate, as controls $(\bigcirc)$. Arrow indicates time of GnRH-PAP or control injections.

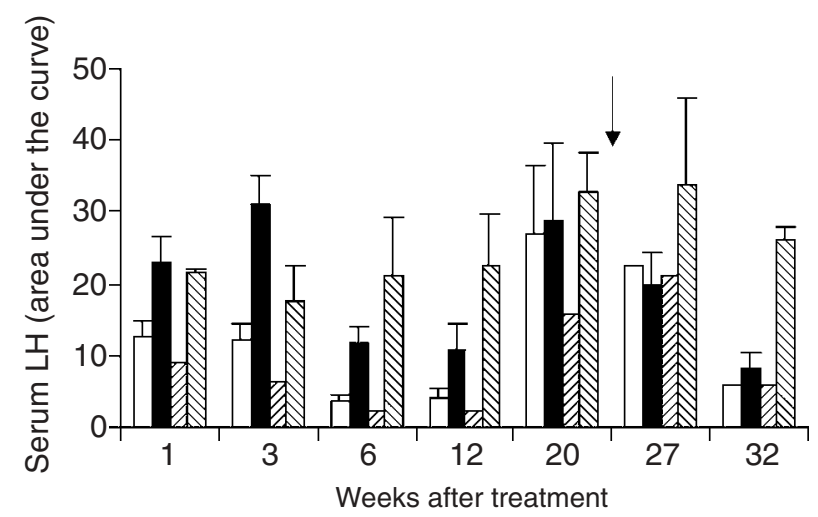

Fig. 2. Serum LH concentrations in male dogs in response to a GnRH stimulation test at weeks 1, 3, 6, 12, 20, 27 and 32 after treatment. Four dogs received $0.0042 \mathrm{mg} \mathrm{GnRH}$-pokeweed antiviral protein (GnRH-PAP) $\mathrm{kg}^{-1}$ hourly for $36 \mathrm{~h}(\mathbf{\square})$. Four dogs received $0.1 \mathrm{mg}$ GnRH-PAP as one bolus injection daily for three consecutive days $(\square)$. One dog received a single bolus $(0.1 \mathrm{mg}$ $\left.\mathrm{GnRH}-\mathrm{PAP} \mathrm{kg}^{-1} ; \mathrm{Z}\right)$. Three dogs received $\mathrm{GnRH}$ without the PAP conjugate, as controls (\$)

groups than in the control group (Fig. 1). Basal LH concentrations decreased $(P<0.05)$ from $3.85 \pm 0.86$ to $1.11 \pm 0.25 \mathrm{ng} \mathrm{ml}^{-1}$ in the bolus group and from $2.37 \pm 0.51$ to $1.03 \pm 0.22 \mathrm{ng} \mathrm{ml}^{-1}$ in the hourly group between week 0 and weeks 14-15 after treatment (Fig. 1). By week 20 after the primary treatment, basal LH concentrations had increased in the treated animals. Serum LH concentrations again declined after the administration of GnRH-PAP in treated animals at week 25 (Fig. 1).

There were treatment $(P<0.05)$ and time $(P<0.01)$ effects on the pituitary release of $\mathrm{LH}$ in response to a $\mathrm{GnRH}$ challenge (Fig. 2). Release of LH subsequent to 


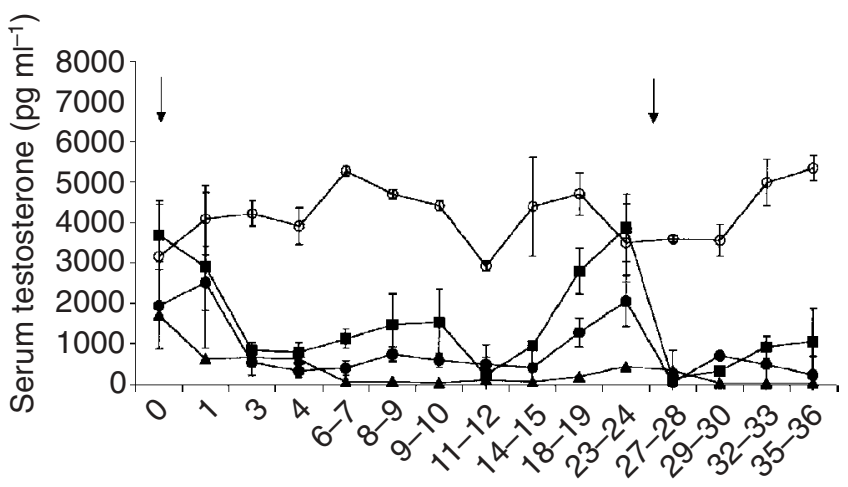

Weeks after treatment

Fig. 3. Serum testosterone concentrations in male dogs treated with $\mathrm{GnRH}$-pokeweed antiviral protein ( $\mathrm{GnRH}-\mathrm{PAP})$ or $\mathrm{GnRH}$ alone, from week 0 to weeks 35-36 after treatment. Four dogs received $0.0042 \mathrm{mg}$ GnRH-PAP kg-1 hourly for $36 \mathrm{~h}$ (ם). Four dogs received $0.1 \mathrm{mg}$ GnRH-PAP as one bolus injection daily for three consecutive days $(-)$. One dog received a single bolus $(0.1 \mathrm{mg}$ $\left.\mathrm{GnRH}-\mathrm{PAP} \mathrm{kg}{ }^{-1} ; \mathbf{\Delta}\right)$. Three dogs received $\mathrm{GnRH}$ without the PAP conjugate, as controls $(\bigcirc)$. Arrows indicate time of GnRH-PAP or control injections.

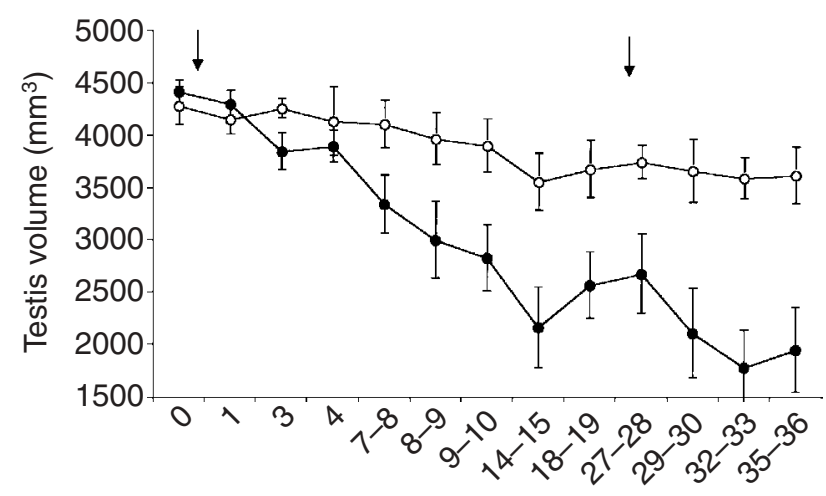

Weeks after treatment

Fig. 4. Testis volume in male dogs treated with $\mathrm{GnRH}-$ pokeweed antiviral protein (GnRH-PAP; 0 ) or GnRH alone (control; $\bigcirc$ ), from week 0 to weeks 35-36 after treatment. Four dogs received $0.0042 \mathrm{mg}$ GnRH-PAP $\mathrm{kg}^{-1}$ hourly for $36 \mathrm{~h}$. Four dogs received $0.1 \mathrm{mg}$ GnRH-PAP as one bolus injection daily for three consecutive days. One dog received a single bolus $(0.1 \mathrm{mg}$ GnRH-PAP kg-1). Three dogs received $\mathrm{GnRH}$ without the PAP conjugate, as controls. Arrows indicate time of GnRH-PAP or control injections.

administration of $\mathrm{GnRH}$ was lower $(P<0.05)$ in the bolus group than in the control or hourly groups. Treatment with $\mathrm{GnRH}-\mathrm{PAP}$ reduced $(P<0.05) \mathrm{LH}$ release in the bolus and hourly groups after $\mathrm{GnRH}$ stimulation to $20 \%$ and $48 \%$, respectively, of area under the curve values for the control group at week 12. However, at week 20, LH release after $\mathrm{GnRH}$ stimulation in the bolus and hourly groups was $84 \%$ and $89 \%$, respectively, of values for the control group (Fig. 2). By week 32 after treatment (that is,

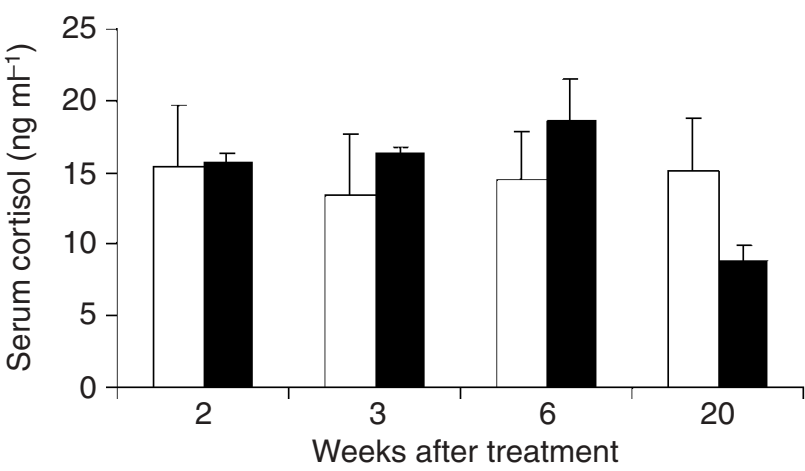

Fig. 5. Serum cortisol concentrations in male dogs treated with GnRH-pokeweed antiviral protein (GnRH-PAP; $\square, n=9$ ) or $\mathrm{GnRH}$ alone (control; $\mathbf{\square}, n=3$ ) at weeks $-2,3,6$ and 20 after treatment.

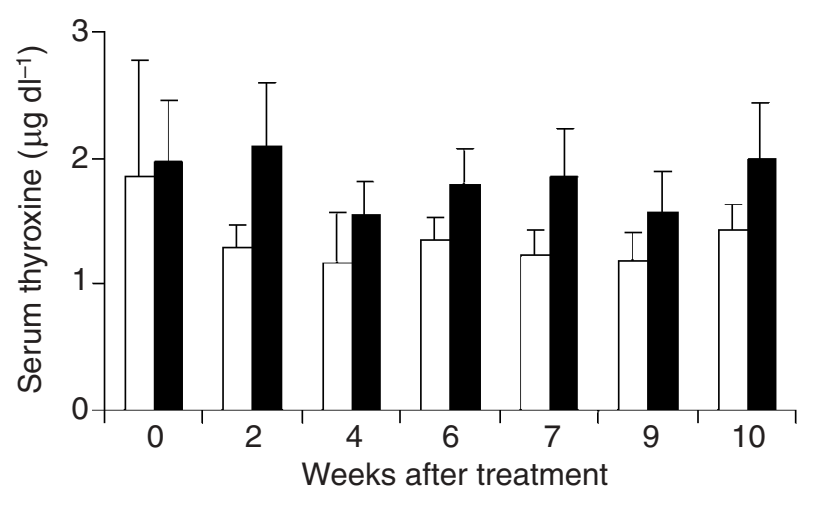

Fig. 6. Serum thyroxine concentrations in male dogs treated with $\mathrm{GnRH}$-pokeweed antiviral protein GnRH-PAP; $\square, n=9$ ) or $\mathrm{GnRH}$ alone (control; $\mathbf{\square}, n=3$ ) from week 0 to week 10 after treatment.

7 weeks after the second treatment with GnRH-PAP), LH release after $\mathrm{GnRH}$ stimulation in the bolus and hourly groups was $22 \%$ and $30 \%$, respectively, of values for the control group.

\section{Serum testosterone}

There were effects $(P<0.05)$ of treatment on serum testosterone concentrations, and bolus and hourly groups had lower $(P<0.05)$ serum testosterone concentrations than the control group (Fig. 3). Serum testosterone concentrations decreased by the third week after $\mathrm{GnRH}-$ PAP treatment and were less than $50 \mathrm{pg} \mathrm{ml}^{-1}$ in three of four dogs in the bolus group and in one of four dogs in the hourly group by week 8-9 after treatment. Testosterone concentrations at week 14-15 after treatment were 11fold and fivefold lower in the bolus and hourly groups, respectively, than in the control group (Fig. 3). However, by weeks 19-20, most treated dogs showed a partial recovery of testosterone secretion (Fig. 3), although testosterone concentrations remained lower than in the control group. Serum testosterone concentrations decreased again after the second treatment with GnRH-PAP 
and were lower at $291 \pm 141 \mathrm{pg} \mathrm{ml}^{-1}$ versus $5396 \pm$ $276 \mathrm{pg} \mathrm{ml}^{-1}, 2$ months after the second injection.

\section{Testis size}

There were effects of treatment $(P<0.05)$ and time $(P<0.01)$ on testis volume (Fig. 4$)$. Testis volume was reduced to $56 \%$ of baseline by weeks $14-15$ in treated animals and $46 \%$ of baseline by weeks $35-36$ after initial treatment.

\section{Changes in peripheral cortisol and thyroxine}

There was no significant effect of GnRH-PAP treatment on either serum cortisol or thyroxine concentrations, indicating that GnRH-PAP treatment was specific and did not adversely affect corticotroph or thyrotroph functions (Figs 5 and 6).

\section{Discussion}

The high specificity and affinity of GnRH for its receptor provides a unique method for delivery of agents to pituitary gonadotrophs that express $\mathrm{GnRH}$ receptors. GnRH acts via G-protein coupled receptors on gonadotrophs to stimulate the synthesis and the exocytotic secretion of gonadotrophins. Sustained exposure to $\mathrm{GnRH}$ is known to reduce $\mathrm{GnRH}$-stimulated gonadotrophin secretion probably through $\mathrm{GnRH}$ receptor internalization and downregulation or uncoupling of signalling and alterations in gonadotrophins (Nett et al., 1981; Conn et al., 1987). GnRH receptors are known to be sequestered from the plasma membrane and internalized via clathrincoated vesicles after stimulation and binding. The internalization of $\mathrm{GnRH}$ receptors in this case allows delivery of the GnRH-PAP conjugate into the gonadotrophs, where the cytotoxin disrupts protein synthesis and results in cell death. PAP, a $30 \mathrm{kDa}$ plant protein isolated from the leaves or seeds of Phytolocca americana, displays a broad spectrum of antiviral activity against different plant and mammalian viruses (Tomlinson et al., 1974; Aron and Irvin, 1980), including the human immunodeficiency virus HIV-1 (Zarling et al., 1990; Uckun et al., 1998, 1999). Conjugates of PAP and anti-CD7 have been used in human and primate trials for therapy of HIV, and the safety of such preparations has been established (Uckun et al., 1999). PAP is an RNA N-glycosidase, which specifically removes an adenine residue from a highly conserved loop in the large ribosomal RNA (Endo et al., 1988). This depurination of the SR loop results in irreversible inhibition at the translocation step (Kurinov et al., 1999) by impairing both the elongation factor 1-dependent binding of aminoacyl tRNA and the GTPdependent binding of elongation factor-2 to the affected ribosome. This inactivates the ribosomes and inhibits protein synthesis, resulting in cell death.
Because GnRH binds with high affinity $\left(K_{d}\right.$ value about $10^{-9} \mathrm{~mol} \mathrm{I}^{-1}$, Srkalovic et al., 1990) to its receptor on the gonadotrophs, the interaction of $\mathrm{GnRH}$ with its receptors has been used to target cytotoxic agents to disrupt these cells within the pituitary. The approach of coupling cytotoxins to $\mathrm{GnRH}$ has been used in the therapy of a number of tumours that possess $\mathrm{GnRH}$ receptors and thereby provide a specific target for the linked cytotoxin (Nagy et al., 1996; Kovacs et al., 1997; Nechushtan et al., 1997; Paalyi et al., 1999). The administration of an analogue of doxarubicin, linked to $\mathrm{GnRH}$, transiently reduced the pituitary secretion of $\mathrm{LH}$ with minimal effects on the secretion of growth hormone or thyroid stimulating hormone from the pituitary (Kovacs et al., 1997).

In vitro studies of a recombinant GnRH-PAP fusion protein demonstrate that the cytotoxicity of this preparation is limited to tumour cell lines that express the $\mathrm{GnRH}$ receptor (Schlick et al., 2000). Treatment with either GnRH alone or PAP alone does not induce cytotoxicity in cells expressing the GnRH receptor. Specificity of the cytotoxic response with GnRH-PAP was confirmed by the competitive inhibition of cytotoxicity between free $\mathrm{GnRH}$ and GnRH-PAP (Schlick et al., 2000). The report of Schlick et al. (2000) confirms that the effects of GnRHPAP are mediated via $\mathrm{GnRH}$ receptors.

The present study demonstrates that GnRH conjugated to PAP disrupts the hypothalamo-pituitary-gonadal axis in adult male dogs. By the third week after treatment, there was a reduction in testis size, serum testosterone and $\mathrm{LH}$ concentrations, as well as a decreased release of $\mathrm{LH}$ in response to $\mathrm{GnRH}$ stimulation. There was no significant difference between the two regimens used (bolus versus hourly), although the dogs that received the bolus injection appeared to show a better response. The dog that received a single bolus also had the lowest $\mathrm{LH}$ and testosterone concentrations after GNRH-PAP treatment.

The suppression of $\mathrm{LH}$ release from the pituitary gland appeared to persist for approximately 5 months after the initial treatment. After that time, there was an increase in basal $\mathrm{LH}, \mathrm{LH}$ response to $\mathrm{GnRH}$ stimulation and serum testosterone concentrations. Administration of a second GnRH-PAP treatment at week 25 again resulted in a suppression of the pituitary release of $\mathrm{LH}$, which persisted to the end of the study at week 36. A subset of treated animals was examined beyond the end of the study at week 36 to week 52 (data not presented). In these animals, basal LH, serum testosterone concentrations and testis size increased to values comparable to the control group by week 52 . These data indicate that administration of GnRH-PAP to intact male dogs suppressed pituitary gonadotrophs for approximately 5-6 months after administration.

In the present study, no adverse side effects were noted subsequent to treatment of adult male dogs with $\mathrm{GnRH}-\mathrm{PAP}$ other than a transient $(<24 \mathrm{~h})$ arthralgia in 
some animals. In addition, there was no significant effect on either serum cortisol or thyroxine concentrations, indicating that GnRH-PAP treatment was specific and did not affect corticotroph or thyrotroph functions. Further studies need to address whether the $\mathrm{GnRH}-$ PAP-induced gonadotrophin inhibition has any effects on other pituitary cells such as somatotrophs or lactotrophs.

In conclusion, the administration of GnRH-PAP to adult male dogs in this study resulted in a major disruption of reproductive parameters by the third week after treatment. Administration of $\mathrm{GnRH}-\mathrm{PAP}$ once per day for 3 days appeared to result in a greater suppression of pituitary LH release than did hourly administration for $36 \mathrm{~h}$ of an equivalent total dosage. Although GnRH-PAP suppressed pituitary release of LH with a concomitant reduction in serum testosterone concentrations and testis size, there was an apparent recovery of pituitary function at approximately 5 months after the first and second administration of GnRH-PAP. It should be emphasized that this trial utilized a single dosage of GnRH-PAP that constituted the best estimate of an effective dosage. Further studies are required to determine whether this approach may be useful to disrupt reproductive function in this species permanently and should include a more thorough dose-ranging study.

This work was supported by the Kenneth A. Scott Charitable Trust; A KeyBank Trust; and NIH CA75662. The authors thank A. Vo and $\mathrm{C}$. Munro for their assistance with the experiments.

\section{References}

Aron GM and Irvin JD (1980) Inhibition of herpes simplex virus multiplication by the pokeweed antiviral protein Antimicrobial Agents Chemotherapy 17 1032-1033

Conn PM, McArdle CA, Andrews WV and Huckle WR (1987) The molecular basis of gonadotropin-releasing hormone $(\mathrm{GnRH})$ action in the pituitary gonadotrope Biology of Reproduction 36 17-35

Endo Y, Tsurugy K and Lambert JM (1988) The site of action of six different ribosome-inactivating proteins from plants on eukaryotic ribosomes: the RNA N-glycosidase activity of the proteins Biochemical and Biophysical Research Communications 150 1032-1036

Irvin JD (1983) Pokeweed Antiviral Protein Pharmacology and Therapeutics 21 371-387

Kendall SK, Saunders TL, Jin L, Lloyd RV, Glode LM, Nett TM, Keri RA, Nilson JH and Camper SA (1991) Targeted ablation of pituitary gonadotrophs in transgenic mice Molecular Endocrinology $\mathbf{5}$ 2025-2036

Kovacs M, Schally AV, Nagy A, Koppan M and Groot K (1997) Recovery of pituitary function after treatment with a targeted cytotoxic analog of LHRH Proceedings National Academy of Sciences USA 94 1420-1425

Kurinov IV, Myers DE, Irvin JD and Uckun FM (1999) X-ray crystallographic analysis of the structural basis for the interactions of pokeweed antiviral protein with its active site inhibitor and ribosomal RNA substrate analogs Protein Sciences 8 1765-1772
Ladd A (1993) Progress in the development of anti-LHRH vaccine American Journal of Reproductive Immunology 29 183-194

Munro C and Stabenfeldt G (1985) Development of a cortisol enzyme assay in plasma Clinical Chemistry 31956

Nagy A, Schally AV, Armatis P et al. (1996) Cytotoxic analogs of luteinizing hormone-releasing hormone containing doxorubicin or 2-pyrrolinodoxorubicin, a derivative 500-1000 times more potent Proceedings National Academy of Sciences USA 93 7269-7273

Nechushtan A, Yarkoni S, Marianovsky I and Lorberboum-Galski H (1997) Adenocarcinoma cells are targeted by the new GnRH-PE66 chimeric toxin through specific gonadotropin-releasing hormone binding sites Journal of Biological Chemistry 27211 597-11 603

Nett TM, Akbar Am, Phemister RD, Holst PA, Reichert LE, Jr and Niswender GD (1975) Levels of luteinizing hormone, estradiol and progesterone in serum during the estrous cycle and pregancy in the Beagle bitch Proceedings Society for Experimental Biology and Medicine $\mathbf{1 4 8}$ 134-139

Nett TM, Crowder ME, Moss GE and Duello TM (1981) GnRH-receptor interaction. V. Down-regulation of pituitary receptors for $\mathrm{GnRH}$ in ovariectomized ewes by infusion of homologous hormone Biology of Reproduction 24 1145-1155

Nett TM, Allen MC, Wieczorek M and Glode LM (1999) A gonadotropinreleasing hormone agonist $(\mathrm{GnRH}-\mathrm{A})$ linked to pokeweed antiviral protein (PAP) decreases the ability of the pituitary gland to secrete $\mathbf{L H}$ Biology of Reproduction $\mathbf{6 0}$ Supplement 1227

Paalyi I, Vincze B, Lovas S et al. (1999) Gonadotropin-releasing hormone analogue conjugates with strong selective antitumor activity Proceedings National Academy of Sciences 96 2361-2366

Schlick J, Dulieu P, Desvoyes B, Adami P, Radom J and Jouvenot M (2000) Cytotoxic activity of a recombinant GnRH-PAP fusion toxin on human tumor cell lines FEBS Letters 472 241-246

Shille VM, Lundstrom KE and Stabenfeldt GM (1979) Follicular function in the domestic cat as determined by estradiol 17 beta concentrations in plasma: relation to estrous behavior and cornification of exfoliated vaginal epithelium Biology of Reproduction 21 953-963

Srkalovic G, Bokser L, Radulovic S, Korkut E and Schally AV (1990) Receptors for luteinizing hormone-releasing hormone $(\mathrm{LHRH})$ in Dunning R3327 prostate cancers and rat anterior pituitaries after treatment with a sustained delivery system of LHRH antagonist SB-75 Endocrinology 127 3052-3060

Tomlinson JA, Walker VM, Flewett TH and Barclay GR (1974). The inhibition of infection of cucumber mosaic virus and influenza virus by extracts from Phytolocca americana. Journal of General Virology 22 225-232

Uckun FM, Chelstrom LM, Tuel-Ahlgren L, Dibirdik I, Irvin JD, Langlie MC and Myers DE (1998) TXU (anti-CD7)-pokeweed antiviral protein as a potent inhibitor of human immunodeficiency virus Antimicrobial Agents and Chemotherapy 42 383-388

Uckun FM, Belllomy K, $\mathrm{O}^{\prime}$ Neill $\mathrm{K}$, Messinger $\mathrm{Y}$, Johnson $\mathrm{T}$ and Chen $\mathrm{CL}$ (1999) Toxicity, biological activity and pharmacokinetics of TXU (antiCD7)-pokeweed antiviral protein in chimpanzees and adult patients infected with HIV virus Journal of Pharmacology and Experimental Therapeutics 291 1301-1307

Zarling JM, Moran PA, Haffar O, Sias J, Richman DD, Spina CA, Myers DE, Kuebelbeck JA, Ledbetter JA and Uckun FM (1990) Inhibition of HIV replication by pokeweed antiviral protein targeted to CD4+ cells by monoclonal antibodies Nature 347 92-95

Received 14 October 2002.

First decision 20 November 2002.

Revised manuscript received 3 February 2003.

Accepted 3 February 2003. 